This is an electronic reprint of the original article. This reprint may differ from the original in pagination and typographic detail.

Author(s): Länsiluoto, Aapo; Järvenpää, Marko; Krumwiede, Kip

Title: $\quad$ Conflicting interests but filtered key targets: Stakeholder and resource-dependency analyses at a University of Applied Sciences

Year: $\quad 2013$

Version:

Please cite the original version:

Länsiluoto, A., Järvenpää, M., \& Krumwiede, K. (2013). Conflicting interests but filtered key targets: Stakeholder and resource-dependency analyses at a University of Applied Sciences. Management Accounting Reserach, 24(3), 228-245. https://doi.org/10:1016/j.mark.2013.02.001

All material supplied via JYX is protected by copyright and other intellectual property rights, and duplication or sale of all or part of any of the repository collections is not permitted, except that material may be duplicated by you for your research use or educational purposes in electronic or print form. You must obtain permission for any other use. Electronic or print copies may not be offered, whether for sale or otherwise to anyone who is not an authorised user. 


\title{
Conflicting interests but filtered key targets: Stakeholder and resource-dependency analyses at a University of Applied Sciences
}

\author{
Aapo Länsiluoto (corresponding author) \\ Seinäjoki University of Applied Sciences; Business school \\ Koulukatu 41 \\ FIN 60100 Seinäjoki, Finland \\ aapo.lansiluoto@seamk.fi \\ Tel. +35840 830 2423, Fax. +358201245401 \\ Marko Järvenpää \\ University of Jyväskylä; School of Business and Economics \\ PO Box 35 \\ FIN 40014 Jyväskylän yliopisto, Finland \\ marko.j.jarvenpaa@jyu.fi \\ Kip Krumwiede \\ University of Richmond; Robins School of Business \\ University of Richmond, Virginia 23173, USA \\ kkrumwie@richmond.edu
}

January 22, 2013

\section{Acknowledgements}

We appreciate the help of research assistant Mr. Mitja Nöjd in transcribing the interviews.

We also acknowledge the case organization and all those interviewed for their positive support of this research project. Finally, we would like to thank Timo Hyvönen, Garen Markarian, John Roberts, Robert Scapens, two anonymous reviewers and the participants in a research seminar in La Trobe University for their constructive comments.

\section{Research highlights}

- This study investigates stakeholders' effect on the performance measurement system (PMS).

- We combine stakeholder (SHT) and resource-dependency (RDT) theories.

- The conflicting interests of stakeholders affected PMS design.

- The conflicting interests did not result in multiple key targets in PMS use.

- One nonfinancial indicator became the most important key target. 


\title{
Conflicting interests but filtered key targets: Stakeholder and resource-dependency analyses at a University of Applied Sciences
}

\begin{abstract}
Stakeholder theory (SHT) emphasizes that different stakeholders and their interests need to be identified and addressed to maximize firm performance. This emphasis can make the design of performance measurement systems (PMS) challenging because the interests of stakeholders are often in conflict. Based on previous research and using stakeholder and resource dependency theories, we develop a theoretical model suggesting that resource dependency acts as a "filter" in selecting which of the PMS design measures are emphasized for decision making. We find various conflicting interests between stakeholders in our case organization (University of Applied Sciences in Finland) that affected PMS design. Contrary to the earlier studies, however, we found that despite conflicting interests, all of the different stakeholders considered one nonfinancial indicator to be the most important: attractiveness, or the number of applicants divided by number of new students. As suggested by resourcedependency theory (RDT), the stakeholder providing the most resources had the most significant impact on the selection of the key performance indicators used. The key resource provider may also have had some effect on the expectations of other stakeholders.
\end{abstract}

Keywords: Performance measurement, stakeholder theory, resource dependency theory, public sector, case study. 


\section{Introduction}

Stakeholder theory (SHT) argues that the utility of a large number of different stakeholders, in addition to the shareholders, is maximized as the firm tries to integrate its needs through the creation of multiple objectives (Christopher, 2010; see also Freeman et al., 2004). SHT has been applied frequently in earlier accounting studies (Orij, 2010; Mäkelä and Näsi, 2010), although almost all of these studies address social responsibility issues (Camara et al., 2009). ${ }^{1}$ A few studies have applied SHT to investigate the stakeholder effect on the design of performance measurement systems (PMS). ${ }^{2}$ These include applying SHT to investigating the development of financial reports (Camara et al., 2009), identifying primary and secondary objectives (Atkinson et al., 1997), designing a PMS in a Chinese case company (Li and Tang, 2009), and balancing multiple objectives in a balanced scorecard (BSC) (Sundin et al., 2010). The paucity of studies indicates a need for further research on performance measurement using SHT.

Previous studies have found that the interests of various stakeholders may lead to an organization's PMS design having a high number of different objectives and measures (Li and Tang, 2009; see also Arnaboldi and Azzone, 2010; Ax and Bjørnenak, 2005; Micheli and Manzoni, 2010). The balanced scorecard approach helps to balance the multiple and

\footnotetext{
${ }^{1}$ Recently, SHT has been utilized in social disclosure (Orij, 2010) or social responsibility (Mäkelä and Näsi, 2010), environmental audits (Darnall et al., 2009), corporate governance (Collier, 2008), and accounting textbook studies (Ferguson et al., 2005). The origin of 'stakeholder' in the management literature can be traced back to 1963, when it appeared in an international memorandum at the Stanford Research Institute. In the organization theory literature, Rhenman (1964 and 1968) used the term stakeholders to designate the individuals or groups which depend on the company for the realization of their personal goals and on whom the company is dependent.

${ }^{2}$ Generally, PMS are expected to have several different positive effects (see for instance Kaplan and Norton, 1996; Kraus and Lind, 2010; Li and Tang, 2009; Sundin et al., 2010). The PMS can be used to align strategy and operations, coordinate and influence employee behavior, balance different objectives, and finally improve organizational performance.
} 
competing objectives (Sundin et al., 2010). On the other hand, previous studies have also shown that PMS design and PMS use are two different concepts (Ferreira and Otley, 2009; Kraus and Lind, 2010; Micheli and Manzoni, 2010, Mouritsen, 2005; see also Sundin et al., 2010). ${ }^{3}$ For instance, Kraus and Lind (2010) found that although PMS design may include a large number of different financial and nonfinancial measures, only certain financial measures are actually used for corporate level control. These financial objectives are sometimes called "primary objectives" (e.g. Atkinson et al., 1997) to emphasize their importance.

The apparent conflict between SHT driving multiple objectives in PMS design while PMS use focuses on only a few primary financial objectives motivates the primary research question for this study: If the interests of various stakeholders are considered in the PMS design, why is PMS use limited to a few primary measures? Prior research suggests it may be that PMS are used to satisfy expectations of key stakeholders (Micheli and Manzoni, 2010) or to maintain the legitimacy of the organization (Modell, 2009). Resource-dependency theory (RDT) predicts that those stakeholders whose resources are the most critical will have the highest impact on the targets used in the PMS (Christopher, 2010; Hillman et al., 2009; Pfeffer and Salancik, 2003). In this study, we investigate whether RDT helps explain why PMS use is limited to a relatively few performance measures in a public sector organization (i.e., a public university). We identify the performance measures included in the PMS and which measures are key to the organization. We also describe the stakeholders and their interests, and investigate how they influence PMS design and usage. The effects on other stakeholders whose interests are not reflected in PMS use are studied to determine the consequences.

\footnotetext{
${ }^{3}$ The widely cited study of Simons (1995) dichotomizes use of PMS as interactive and diagnostic (see for instance Micheli and Manzoni, 2010).
} 
This study contributes to the PMS literature in several ways. The major finding and contribution of the study is that the conflicting interests of stakeholders do not necessarily lead to a large number of key indicators used for decision making, which contradicts the basic proposition of stakeholder theory. We develop a theoretical model suggesting that the process of selecting the key indicators is complex and that resource dependency acts as a "filter" in selecting certain measures as primary. This case organization's stakeholders and their expectations are described in more detail than earlier studies (e.g. Atkinson et al., 1997; Kraus and Lind, 2010; Li and Tang, 2009; Sundin et al., 2010). We find ample evidence that the resources supplied by certain stakeholders significantly impacted the key measure focused on (Christopher, 2010; Hillman et al., 2009) and discuss how it happened at the case organization. Various key stakeholders of the university considered one nonfinancial indicator to be very important: attractiveness, or the number of applicants divided by number of new students. This finding differs from the typical for-profit firm focusing on net income as the single key indicator and assuming it takes care of all stakeholder interests. Here, attractiveness is a major leading indicator of financial results as well as a crucial measure of survival for individual campuses within the university system.

The paper is organized as follows. First, we discuss prior PMS studies using SHT and RDT and establish a theoretical foundation for our research question and model. Second, we describe the methodology used for this exploratory qualitative case study. Third, we present empirical results which identify stakeholders, their interests, and the resources they provide to the case organization, as well as what measures are included in the PMS design and why a single nonfinancial measure is the key metric used. Next, we discuss the results and contributions of this study in light of prior research and theory. Finally, we provide conclusions, limitations, and implications for further research. 


\section{Prior studies and theoretical foundation}

\subsection{Stakeholder theory}

This study applies stakeholder theory (SHT) because it enables identifying different stakeholders (e.g. Darnall et al., 2009), investigating their various interests (e.g. Christopher, 2010), learning how these sometimes competing interests are managed (Collier, 2008), and determining the key performance indicators (KPI) of the different stakeholders (e.g. Atkinson et al., 1997; Li and Tang, 2009; Sundin et al., 2010).

The definition of stakeholder by Freeman (1984) is widely applied (e.g. Christopher, 2010; Collier, 2008; Darnall et al., 2009). According to Freeman $(1984,46)$, a stakeholder is "any group or individual who can affect or is affected by the achievement of an organization's objectives.” In addition to Freeman's (1984) definition, Donaldson and Preston (1995) have further developed the definition as "persons or groups with legitimate interests in procedural and/or substantive aspects of corporate activity." Stakeholders need to be identified first if SHT is to be applied (see for instance Collier, 2008). ${ }^{4}$ Stakeholders usually include shareholders, managers, lenders, institutional investors, employees, government, creditors/suppliers, debtors, customers, analysts and other wider issues (i.e., natural environment, general public, community, society) (Atkinson et al., 1997; Darnall et al., 2009; Ferguson et al., 2005; Freeman et al., 2004; Waddock et al., 2002).

Different stakeholders participate in the operations of organizations because they want to obtain something which benefits their own objectives (Donaldson and Preston, 1995). The interests of stakeholders can be either competing or common. The challenge for managers in

\footnotetext{
${ }^{4}$ Several different alternatives are available for categorizing stakeholders (e.g. Donaldson and Preston, 1995). Stakeholders can be cooperative/competitive (Donaldson and Preston, 1995), environmental/process (Atkinson et al., 1997), internal/external (Darnall et al., 2009), owner/non-owner (Li and Tang, 2009), or primary/secondary (Waddock et al., 2002). Finally, stakeholders can be categorized by their interests and power (Ackermann and Eden, 2011) or by forces which affect an organization (Collier, 2008).
} 
following stakeholder theory is how to specify and make tradeoffs between the conflicting and inconsistent demands of different stakeholders besides just shareholders (Sundin et al., 2010; Jensen, 2001; Donaldson and Preston, 1995). In particular, managing multiple objectives has been criticized (Jensen, 2001; Li and Tang, 2009; Sundin et al., 2010). Li and Tang (2009, p. 194) claim that "stakeholder theory fails to provide corporate managers with a single objective, which might result in managerial confusion, conflict, or even competitive failure." Also, Jensen (2001) proposes that "since it is logically impossible to maximize more than one dimension, purposeful action requires a single valued objective function." Contrary to Li and Tang (2009) and Jensen (2001), Freeman et al. (2004) propose that having one objective makes governance and management difficult if not impossible due to the world's complexity. On the other hand, maximizing shareholders' wealth in the long-term may indicate that the interests of other stakeholders are being considered (see for instance Christopher, 2010).

\subsection{Prior performance measurement studies with SHT}

SHT has been applied to investigating PMS in earlier studies (Atkinson et al., 1997; Li and Tang, 2009; Sundin et al., 2010). These three studies all suggest that stakeholders may affect the design of PMS. ${ }^{5}$ Each study gathered qualitative data from a single company and used either action research (Li and Tang, 2009), exploratory (Sundin et al., 2010), or illustrative (Atkinson et al., 1997) case study approaches. Atkinson et al. (1997) analyze both primary and secondary objectives for four different groups of stakeholders—shareholders, customers, employees and community—at the Bank of Montreal. Li and Tang (2009) studied

\footnotetext{
${ }^{5}$ Different stakeholders may have a different effect on other types of management control systems besides PMS. For instance, Darnall et al. (2009) found that environmental audits used by organizations are positively associated with perceived influence from internal, regulatory, and supply chain stakeholders. However, environmental audit use was not related to the perceived influence from societal stakeholders (Darnall et al., 2009).
} 
a large Chinese state-owned firm and propose a stakeholder framework which illustrates how PMS design is affected by owners and non-owners. According to the framework of Li and Tang (2009), owners define objectives, strategy and critical performance variables which are affected by the contributions and expectations of non-owner stakeholders.

The balanced scorecard (BSC) approach has been found to help balance multiple and competing stakeholder objectives. Sundin et al. (2010) found the BSC approach was effective in balancing the desires of various stakeholders in an electric utility company. These findings support the Ax and Bjørnenak (2005) proposition that the BSC can be applied to balance the needs of different stakeholders such as owners, customers, and employees. ${ }^{6}$ Sundin et al. (2010) also found other factors besides the BSC were helpful for balancing objectives, including explicit desire for balance, stakeholders' ability to exert pressure, other formal management control systems, and organizational culture and leadership.

A potential limitation of the BSC approach is that it has been found to have limited impact on control, i.e., PMS use. The results of Kraus and Lind (2010) indicate that nonfinancial indicators are not as intensively used as expected although the organization designed them into the BSC. They found that the Swedish companies used financiallyfocused measures for control in corporate-level. Moreover, they found that financial indicators (i.e., ROCE, EBITDA, and EBIT) were most important. Standards were only set for financial measures and rewards were largely based on these financial performance measures. Kraus and Lind (2010) explain some internal and external reasons for financialoriented control. Internal reasons relate to simplicity and comparability between business units and competitors. External reasons relate to capital market and pressures from analysts who were assumed to be interested only financial accounting measures. Therefore, the results

\footnotetext{
${ }^{6}$ According to Ax and Bjørnenak (2005), PMS design usually included the employee perspective in the Swedish public sector organizations.
} 
of Kraus and Lind (2010) suggest that only certain stakeholders have a significant impact on the key PMS measures used for decision making even though the PMS design may have a large number of different measures.

Together these prior studies indicate that stakeholders do affect PMS design and use. However, what is still not understood is why some stakeholders seem to have more impact on the primary measures than other stakeholders. One potential explanation is provided by resource dependency theory as explained next.

\subsection{Resource dependency theory}

According to Frooman (1999), two parameters affect how much power the stakeholders may have concerning the organization and its PMS design: how dependent the organization is on the stakeholder and how dependent the stakeholder is on the organization. Based on this framework, the stakeholder has the most power when the firm is highly dependent on the stakeholder. The degree of dependence on the stakeholder can be investigated through resource dependency theory (RDT). According to RDT, a stakeholder's ability to exert pressure may stem from its ability to provide resources.

The resource is a fundamental concept in RDT because organizations require resources to operate. Organizations are linked to different environments (such as federations, associations, customer-suppliers, competitive relationships) to acquire needed resources (Pfeffer and Salancik, 2003, p. 2). The resources might be provided internally or externally. A balance sheet illustrates some of the resources that organizations own relating to assets, liabilities, and shareholders' equity. But there can also be several other different assets such as physical, human, procedural, or marketing assets not reported on the balance sheet (Kamminga and Van der Meer-Kooistra, 2007). Any of these various assets can be critical to the success of the enterprise. 
Previous studies have investigated how resources affect control systems. Abernethy and Chua (1996) find institutional pressure in a hospital organization was exerted primarily through powerful state funding agencies which provided 90 percent of the organization's financial resources. This pressure led to changes in different aspects of the management control system. Frooman (1999) proposes that if stakeholder power is high then the stakeholder will choose a direct withholding strategy to influence the firm. Frooman (1999) defines withholding as a situation "where the stakeholder discontinues providing a resource to a firm with the intention of making the firm change a certain behavior." Also, Kamminga and Van der Meer-Kooistra (2007) illustrate three different management control patterns for joint venture control. These different control patterns were affected by the type of resources, (i.e., their measurability and specificity). In his statistical study, Dekker (2008) found resource dependence relating positively and significantly to governance extensiveness. These studies support the basic idea of RDT by showing that resource dependence has impact on control systems.

Organizations have applied several different alternatives to cope with the environment and decrease their resource dependency. According to Hillman et al. (2009; see also Pfeffer and Salancik, 2003), these alternatives relate to, for instance, mergers and acquisitions, joint ventures, boards of directors, political action and executive succession. The role of the board seems to be the most interesting for this study. RDT suggests that the board of directors can manage internal and external environmental dependencies (Christopher, 2010; Hillman et al., 2009; Pfeffer and Salancik, 2003).

Previous studies have suggested combining RDT and SHT in forthcoming studies but they have not proposed specific dependencies or collected empirical data (Christopher, 2010; Hillman et al., 2009). Although RDT is applied extensively in earlier studies, RDT seems to be a valuable addition to SHT because both theories recognize the organizations' 
interdependence on internal and external stakeholders (Hillman et al., 2009). Hillman et al. (2009) suggests that earlier RDT studies have not specified which resource dependencies are the most important if multiple important dependencies exist. In conjunction with the proposition by Hillman et al. (2009), Christopher (2010) constructs a multi-theoretical framework for investigating the forces impacting organizations including four theories: agency, resource dependency, stakeholder, and stewardship theories. Christopher (2010) recommends validating the multi-theoretical framework because empirical data was not used.

\subsection{A Theoretical framework}

Building upon prior research and following the suggestions of Hillman et al. (2009) and Christopher (2010), we integrate RDT and SHT into a theoretical framework. Figure 1 summarizes our theoretical framework describing how stakeholders and their resources affect the process of selecting key performance indicators. First, as suggested by SHT, all organizations have many stakeholders with both common and conflicting interests. These interests lead to multiple measures in the design of PMS as the organization strives to meet these interests.

\section{[Insert Figure 1 about here]}

However, as proposed by RDT, the organization is dependent on the resources provided by certain stakeholders and not dependent (or less dependent) on others. This dependence leads to certain key measures being filtered out from among the large number of measures based on the resource criticality of the stakeholders. The more critical the resources provided by a stakeholder, the more important are their interests for the organization, leading to the use of measures relating to those interests for decision making.

Our theory, for why some measures in the PMS design are focused on and others are not in PMS use, is different to the institutional theory. The institutional theory argues that firms may ceremoniously conformto a directive of the parent company such as measures in 
PMS design (Siti-Nabiha and Scapens, 2005; Burns and Scapens, 2000; Meyer and Rowan, 1977). Those ceremonially institutionalized routines, or "organizational rituals," help preserve the status quo and the power or interests of specific groups or individuals, rather than aid decision making. In contrast, our model for which measures are used for decision making is based on resource dependency rather than ownership or institutionalism. First, the measures in the PMS design are driven by diverse stakeholders with often conflicting interests, including those measures used for decisions. Second, it is the higher level of resources provided by certain stakeholders that put their interests and related performance measures higher on the priority list. This filtering process should be especially keen in public sector or non-profit organizations that are totally dependent on financing from external sources rather than generating their own income.

Finally, the use of these key measures will have both desirable and undesirable consequences for the case organization and its stakeholders. The organization is expected to benefit through increased resources to implement firm strategy, higher motivation and learning (Micheli and Manzoni 2010), or higher profitability (e.g. Atkinson et al. 1997). Stakeholders providing significant resources and others with common goals will benefit through firm decisions that are more consistent with their interests. On the other hand, we expect less desirable consequences for those stakeholders not providing significant resources (or with conflicting interests from those that do) to the firm and perhaps for the long-term success of the organization. These outcomes include important stakeholder interests not being met (e.g., local economies) or risks to the long-term viability of the organization itself (e.g., environmental liabilities).

\subsection{Public sector vs. For-profit organizations}

Finally, we expect the primary performance targets for a public sector organization to be somewhat different from those in for-profit firms (Kraus and Lind, 2010; Atkinson et al., 
1997). The potential for conflicting objectives is particularly strong in public sector organizations because the overriding purpose is not as clear as in private companies- to generate profits for the shareholders (Arnaboldi and Azzone, 2010). ${ }^{7}$ Due to this non-profit nature, perhaps other stakeholders besides only shareholders have a higher impact on a public organization than on a private firm. In addition to an unclear purpose, the ownership structure is often unclear in public sector organizations (Broadbent and Guthrie, 2008). These two issues might be reasons why Arnaboldi and Azzone (2010) claimed that public sector organizations have difficulties in setting targets. ${ }^{8}$ In their 11-year longitudinal study of a university, they found that defining a single key measure was never pursued. In this study, we investigate whether the performance targets for a public sector organization are primarily financial measures as is common in for-profit firms (Kraus and Lind, 2010; Atkinson et al., 1997), and if not, how they are different and why.

\section{Research method}

We adopt an exploratory qualitative case study approach (Ryan, Scapens and Theobald, 2002; Sundin et al., 2010). This approach allows us to gather information about the influence of stakeholders and resource dependency — as well as the PMS design and key measures-for an organization that is not available through public sources or survey data. We began with a theoretical model informed by previous research. Next, we investigate the case organization at a very detailed level using multiple sources of evidence to more fully develop our theoretical model. We applied abduction reasoning when we developed theoretical explanations to empirical observations (Dubois and Gadde, 2002; Lukka and Modell, 2010).

\footnotetext{
${ }^{7}$ Broadbent and Guthrie (2008) review the literature on public sector accounting studies. Modell (2009) focused more particularly on the public sector PMS accounting literature with institutional theory.

${ }^{8}$ According to Arnaboldi and Azzone (2010), other difficulties of PMS implementation were related to the diverse nature of services, the wide range of users and lack of competencies in the public sector.
} 
Therefore, the final version of the theoretical model in Figure 1 was developed after reviewing the literature and analyzing empirical observations.

\subsection{The case organization}

Several criteria were used to select the case organization for the study. First, we wanted to study a public organization. Due to its non-profit nature, more stakeholders may have an impact on a public organization's PMS than in a for-profit firm. We also wanted to study how the primary performance targets for a public sector organization differ from those in for-profit firms. The second and third criteria were of a more practical nature. The second criterion was that the case organization needed to be willing to participate in the research project so that we could have good access. The third criterion was that the organization should be one that has been reported on in the media, indicating the importance of the organization to the local area as well as enabling the use of different data sources such as newspaper articles.

The Case University of Applied Sciences (hereafter XUAS ${ }^{9}$ ) met well the criteria for this study. The Finnish higher education system has two types of systems: universities of applied sciences $\left(\mathrm{UASs}^{10}\right.$ ) and universities. The universities conduct scientific research and provide graduate and postgraduate education. UASs educate professionals in response to labor market needs and conducts $R \& D$ that supports education and promotes regional development in particular (MEC, 2010). All Finnish universities are public and students are selected by an exam. The tuition is free for the students after they have passed the exam.

\footnotetext{
${ }^{9}$ The acronym "XUAS" is used when referring to the case organization.

${ }^{10}$ Acronym "UASs" refers all the universities of applied sciences in Finland including XUAS. Finland has only one UASs.
} 
The first university of applied sciences started to operate in 1991. The total number of UASs students is 130,000 and it awards over 20,000 Bachelor-level degrees and 200 Masterlevel degrees annually (MEC, 2010). In 2010, there were 25 different UASs in Finland. XUAS has several thousand students and offers about 20 different Bachelor-level and five Master-level degree programs. XUAS has several different units in different municipalities. XUAS main campus with several XUAS units is located in a municipality that is a regional center of the area. The maximum distance between different units in XUAS is about two hundred kilometers. All XUAS units are located within one hundred kilometers from the main campus of XUAS. XUAS is owned by a municipal consortium (MC).

\subsection{Data gathering and analysis}

The empirical data was collected via six preliminary interviews and twenty three semi-structured follow up interviews. All the people interviewed are listed in the Appendix. The preliminary interviews were conducted by one of the researchers of this study. The preliminary interviews were not voice-recorded but field notes were taken during interviews. The purpose of these preliminary interviews was to gather more information about the future research project and gauge the interest level. The preliminary interviews investigated the general PMS and management control environment in the case organization. Follow up interviews also investigated the stakeholders and their expectations.

We selected different types of interviewees to achieve a better understanding of the phenomena. We interviewed internal parties such as students, unit management and XUAS board level directors. We also interviewed XUAS external parties such as representatives of a municipality, the national government, and some local firms. We had good access to XUAS. Therefore, we were able to interview all the representatives necessary for our research purposes. 
At least two researchers participated in the semi-structured interviews to help ensure the accuracy, relevance, and validity of interview data (see also Li and Tang, 2009). A research assistant also participated in some interviews when XUAS internal parties were interviewed so that the assistant could transcribe the voice recordings more easily. All the interviews were voice recorded and transcribed into text later. We usually spent from 90 minutes to two hours with those interviewed. The duration of recorded interviews varied from fifty to one hundred minutes. Some interviews were conducted after the first interviews revealed unexpected and important stakeholders for the organization. All the interviews were conducted in the interviewees' native language which was Finnish. Therefore, all the quotations in this paper have been translated into English. Consequently, different shades of meaning may emerge due to translation, even though we have tried to be extremely careful in conducting the translation.

The empirical data analysis started by indexing and identifying the stakeholders. The indexes were used to explore and connect the interests of stakeholders and their targets. Next, we analyzed the different resources of stakeholders because earlier studies have indicated that resource dependency and criticality has an effect on control systems. In addition to interview data, we also accessed public data sources and internal documents for identifying the issues and connected them to findings of the interviews using the same indexing system.

We have utilized several data sources to increase the reliability of the results ( McKinnon, 1988; Sundin et al., 2010; Vaivio, 2008). First, we utilized several different types of data including annual reports, public documents (i.e., the web-pages of UAS and Ministry of Education and Culture, Finnish acts and laws, Finnish statistics, newspapers), internal documents (i.e., financial statements, quality assurance manual, performance measurement reports), personal e-mails (sent to all employees by researchers), interviews and direct observation. We had access to XUAS intranet. Second, we had several different participants 
in the interviews. The interviewees varied according to their organizational position. We interviewed both internal and external parties of XUAS. Third, at least two researchers participated in all interviews (with exception of the preliminary interviews). Fourth, we allowed as much time for interviewing and observing as was required.

\section{Case Description}

This section discusses the case study findings and begins by identifying the key stakeholders, their interests, and their performance targets that impact PMS design. Next, we identify the kinds of resources that different stakeholders provide, and how certain stakeholders and their resources affect the key XUAS performance measure.

\subsection{Key stakeholders and their interests}

The interviews revealed several different stakeholders. One of the most frequently mentioned stakeholders was the Ministry of Education and Culture (MEC). Another frequently mentioned group of stakeholders was the municipalities where XUAS is located. The importance of these two entities can be observed from the following quotation:

"There are two institutes who offer financial resources: the government, or the MEC, and the municipalities. They are important stakeholders when we are considering external stakeholders" (XUAS president).

Ministry of Education and Culture (MEC). One of the most important stakeholders is the MEC because it provides a large part of the financial resources for XUAS. According to XUAS financial statements, the MEC provides the largest proportion of financial resources to XUAS. Although over half of MEC's financial resources provided to UASs were collected from Finnish municipalities, the financial support from municipalities flows to different universities in UASs, including XUAS, through the MEC. Thus, the MEC holds a gatekeeper position regarding the financial resources. The MEC launched a structural development program in March 2008 which set a goal that the maximum number of Finnish UASs is to be 
18 , each with at least 2,500 full-time students by 2020 . Achieving this goal requires structural changes (i.e., UAS mergers or closures) because there were 25 different universities of applied sciences including six that had less than 2,500 full-time students when the structural development program was launched. This target was mentioned extensively in several different interviews. An interviewed MEC director explained that successful UASs is able to change its structure:

"The successful UAS [in general] has been capable of rearrangements-able to get out of the old mode of action and is open-minded to new structural changes that enable it to take the next development phase. Thus, different UAS have been the best in different eras... [The successful UAS] is capable of clearly specifying its future prospects; the strategy has to be able to delete [something old], not just include all existing operations so that everybody would be happy" (Director of education, MEC).

According to the structural development program of the MEC, UASs performance is evaluated by the following criteria: attractiveness (i.e., number of student applicants per number of new students), time to graduate, number of scientific publications, effective resource utilization, student employment, and lifelong learning. The evaluation of these different criteria is conducted annually and all units within Finnish UASs are ranked against each other. The MEC sent written feedback to all these units with UASs during the time of our field research. ${ }^{11}$ The XUAS received the following feedback, which is particularly focused on the "attractiveness" of degree programs:

"The structure of degree programs needs to be restructured [in XUAS]. The attractiveness of the degree programs has been below the Finnish UASs average in the majority of XUAS degree programs. Furthermore, the size [i.e., number of students] of degree programs has been below MEC suggestions in the majority of degree programs. The attractiveness ratios have been very low especially in [certain specifically named] units and municipalities." (MEC feedback to UAS, November 12, 2010)

\footnotetext{
${ }^{11}$ The MEC sent another feedback report to XUAS in October 2011. Due to low attractiveness ratios in the feedback report, MEC forced XUAS to close three specified units. All the units were located outside of XUAS main campus in smaller municipalities of the region. After the XUAS reply to the feedback, the MEC sent a final decision to XUAS in March 2012 forcing closure of the specified units.
} 
Municipalities. The municipalities were often mentioned as important stakeholders for XUAS. The mayor of XUAS's largest city mentioned the importance of having qualified employees from XUAS.

"XUAS is extremely important to our city and our business in this area. [XUAS] can stop the large part of the youth movement [to other cities]. The first target of our XUAS is to stay amongst those 18 remaining UASs. It is also important to our businesses in this area because [XUAS] educates new and qualified employees for them. Education and research and development are naturally very important to our business" (Mayor of the largest municipality in XUAS the area).

The municipalities sometimes have conflicts between each other when they are

defending their own interests. This conflict was observed particularly in restructuring issues, such as whether to close units or move them closer to the biggest city of the region.

"When we have units in different municipalities, they recognize only their own narrow interests without recognizing wider issues. We have to battle this fight because [municipalities] do not recognize that [XUAS] benefits our province when we have UASs-level education and research here. This [education and research] contributes to our industry and business" (The Chairman of Board of MC \& Vice Member of Board of the largest city in XUAS area)

"The municipalities naturally hope the education [and units] are not moved anywhere and their education needs will be met [in their municipality]... I understand extremely well the worries of mayors about what happens when the UAS unit is moved away" (Vice President of XUAS).

The plans to move XUAS units into the main campus or close by were mentioned

extensively in local newspapers. The following are some examples.

"Student Union would centralize the education with the main campus with certain conditions (Headline). ... Union believes that centralization will enrich the substance of the degree programs, develop the quality of the education and improve the attractiveness." (Local newspaper, April 22, 2011)

"It is time to give up (Headline). It might be the time to give up. Everything will be centralized - of course. This is going to happen for instance to (XUAS) education in [a certain municipality]. XUAS management is reaching its longterm goal after many years of effort. [The specific unit in XUAS] is going to be deserted..." (Opinion in local newspaper, April 29, 2011). 
Local firms. Local firms are also an important group of stakeholders which can be found in several different places in XUAS strategy. Those interviewed mentioned the local firms' importance to XUAS. One Dean commented, "We are doing applied research and it naturally requires some firms." Another Dean said, "Important stakeholders are naturally these business partners."

Like the municipalities, local firms also want qualified employees from XUAS. The CEO of the local entrepreneurs' organization cited this desire and recognized that the attractiveness of the city and XUAS are important factors for them:

"[XUAS] teaching is extremely important for the development of this area. I think that [XUAS] has had a very significant impact on the attractiveness and development of this city during the last twenty years. Attractiveness is important. We can't force anybody to come to study here. The attractiveness factor [of the city and XUAS] has to be good which is a challenge here... This area also needs to be attractive for investors so that new firms want to be established here. We can find [qualified] employees elsewhere if we don't have them in this area already." (CEO of the Regional Organization of Enterprises).

Expectations for XUAS differed between local firms although they all expected qualified employees from XUAS. The size of the firm affected these expectations. The larger firms in XUAS area have different levels of cooperation with XUAS than smaller firms as was observed:

"There are two types of firms: self-employed people and firms who are employers... the mode of cooperation differs between these self-employed people and employer firms... My opinion is that these larger firms understand how to cooperate with XUAS. The majority of firms have less than 9 employees; the challenge is how these smaller firms are able to cooperate [with XUAS]" (CEO of The Regional Organization of Enterprises).

Students. XUAS strategy statement defines students as one of the most important stakeholder groups. Their importance is recognized in UASs Act (351/2003) which states that students must be included on the UASs board. The importance of students for XUAS was recognized both in interviews with students themselves and with XUAS managers. One of the 
Deans commented, "Students are our stakeholder number 1." The following comment is another example:

"Everybody's ideas are recognized, the students are part of this [XUAS management] system. The student is in some ways a king [of the system]. Also, directors have said somewhere that students are the most important; without students this XUAS does not exist" (Secretary-general of XUAS student union).

Students thought that a successful UAS is one that is attractive for students and has good teaching quality. The students also felt that, in addition to the UAS, the municipality should also be attractive. They consider higher attractiveness to affect UAS existence in the future:

"The attractiveness of both [the biggest] city and UAS has been the greatest challenges here. I think that enough large and attractive units would be crucial. Attractiveness is important for the existence of this UAS. If we want this UAS to exist after ten years [the attractiveness is very important]" (Secretary-General of XUAS student union).

Public organizations. Those interviewed mentioned other public organizations as stakeholders such as the European regional development fund (ERDF), European social fund (ESF), Finnish Funding Agency for Technology and Innovation (TEKES), and other Finnish universities of applied sciences [ARENE]. ${ }^{12}$ A specified public regional organization (i.e., hospital district) was also mentioned as an important stakeholder in the interviews. The importance of these public organizations, especially for research and development, can be observed from the following quotation, "We should apply for even more funding from [the Finnish] academy and TEKES although we have already applied" (Research and Development director of XUAS). In addition, XUAS President said, "In the field of social services and health care, a regional hospital district is a very important stakeholder."

\footnotetext{
${ }^{12}$ In particular, XUAS Deans mentioned that the other XUAS units are one of their important stakeholder groups. Quotes included: "This unit has a lot of cooperation with [XUAS] units... It [i.e., cooperation] works very well" (Dean), and "[The meetings with other Deans] are very important" (Another Dean).
} 
These public organizations expect good research and development applications from XUAS which promote economic and social development. The ESF webpage states that "ESF reduces differences in prosperity and living standards across EU member states and regions, and therefore promotes economic and social cohesion." On the other hand, the TEKES webpage shows that TEKES boosts wide-ranging innovation activities in research communities, industry, and service sectors. TEKES aims to fund research, development and innovation which benefit the economy and society in the long-term.

In summary, SHT enabled us to identify the key XUAS stakeholders which are the MEC, municipalities, students, local firms, public funding organizations (e.g. ERDF, ESF), and other universities. This list indicates that XUAS has both internal (e.g. students) and external (e.g. firms, MEC, and municipalities) stakeholders.

\subsection{The PMS design}

The PMS design is based on the BSC approach ${ }^{13}$ and certified quality system in XUAS. The BSC approach was selected because it enabled XUAS to set targets and it was generally accepted.

"BSC has a central role because different issues have to be measured. This approach of Kaplan and Norton needs to be included because it makes [the target setting process] more structured." (Dean of XUAS)

According to internal documents, their BSC has five perspectives which are customers, internal processes, partners, personnel and resources. The BSC has from two to six critical success factors (CSF) for each of the five perspectives. Each CSF has a specified indicator which is generally set for XUAS and each unit. The total number of CSF and targets is 18 , of which only four are set for each specific XUAS unit. Fifteen targets are set and

\footnotetext{
${ }^{13}$ According to the published XUAS strategy (p. 9),"13 people have been creating the XUAS strategy [for the years 2010-2015] including representatives of XUAS employees, students and external stakeholders".
} 
measured at the XUAS level. The strategy team tried to limit the number of targets in designing the PMS. As the XUAS President stated, "We have tried to limit the number of strategic targets to 10-15 indicators."

Table 1 shows the internally published PMS design in the case organization. According to Table 1, the first measure in the PMS design is attractiveness and is located in the customer perspective. Table 1 also shows that the PMS design includes 18 different formal measures that reflect the interests of various stakeholders. The attractiveness measure supports the interests of all stakeholders to some extent, but especially the MEC. Indicators like Employment rate and Employment in the region reflect the interests of municipalities and local firms, respectively. The interests of students (e.g., Drop outs, Employment rate, ands Student satisfaction) and other public organizations (e.g., External finance of research, development and innovation (RDI)) are also considered in the PMS design.

\section{[Insert Table 1 about here]}

The data for the measures are collected from financial reports, statistics, student surveys, personnel surveys, the course feedback system and other data sources. According to interviews, the PMS design was affected by two main factors: data availability and the interests of stakeholders.

"BSC must be understood so that there are rough, brutal and even inappropriate measures. The measures need to be of this kind where we have data. It doesn't make sense to create measures where data is not available easily and fast" (Vice President of XUAS)

The working groups formulating the strategy tried to figure out the stakeholder needs in strategic planning rounds in 2003 and 2008. Moreover, the structure of the BSC model actually enabled this by labeling the perspectives as "partners," "owners," and "personnel" (later on separate perspectives for "customers" and "partners" were added). For example, the 
internal evaluation study, which was made after the 2002-2003 PMS development and strategy process, states:

"Thinking about the future development of the BSC, both students and firms are desired as equal partners. From the very beginning of the BSC system and strategy process it was desired to use the term "partners" and not "customers". A partner perspective is considered of high importance for the organization and its design has been successful regarding both the number of measures and the perspective. [...] Partner perspective will probably be developed into a strong and essential perspective as a part of the strategy." (BSC evaluation study, 2003)

For instance, the MEC targets were included in the BSC as can be found from the following quotations.

"The MEC requires quite many different measures. They should be incorporated [in BSC] so that we would not have two different performance measurement systems" (Dean of XUAS)

"Majority of measures of the [MEC] ministry are also our key targets in our strategy, I guess that they would be also in future" (Development manager of XUAS).

In addition to the MEC, other stakeholders have had representation on the PMS design team including students, entrepreneurs, and municipalities. A representative of the largest municipality participated in the strategy work as a member of the municipality board.

"External stakeholders and students have always had some effect on these [strategic] measures." (Development manager of XUAS)

"We have participated in different development projects. We have been involved in [XUAS] strategy process..." (Secretary-General of XUAS student union)

In summary, we find that the interests of the various stakeholders are carefully included in the PMS design at XUAS. There are also a great number of targets both at the unit and XUAS levels that are linked to XUAS strategy. ${ }^{14}$ Next, we discuss the resources provided by the different stakeholders and how they impact the key target measure at XUAS.

\footnotetext{
${ }^{14}$ The case organization has also launched a specific strategy for international activities and has constructed a BSC for implementing the strategy. This BSC for international strategy also has targets for different CSF and
} 


\subsection{Resources of different stakeholders}

This section analyzes the resources that different stakeholders offer to XUAS. One of the most frequently mentioned stakeholders was the MEC. One reason for MEC's importance is that it provides the largest part of the financial resources for XUAS operations. According to XUAS annual report, the MEC provides over 75 percent of total income. However, the MEC does not have any official representatives on XUAS board.

Municipalities were also mentioned as a stakeholder group providing significant resources. According to the financial statements, the municipalities finance XUAS directly although its direct proportion ${ }^{15}$ is not as high as the direct proportion of MEC's. All the Finnish municipalities have to pay a certain amount per habitant to the government (Salminen and Ylä-Anttila, 2010). This payment is reallocated by the MEC to the different UASs for their operations. ${ }^{16}$ MEC's webpages show that almost 55 percent of its financial resources are provided by the municipalities and the rest are provided by the Finnish national government. The payments by the municipalities are made even if they do not have XUAS unit in their municipality. Figure 2 shows that municipalities provide financial resources both directly (arrow A in Figure 2) (e.g., securing loans) and indirectly via the MEC (arrows B and C in Figure 2).

\section{[Insert Figure 2 about here]}

includes different targets for attractiveness concerning international activities. These attractiveness targets include number of applicants for degree programs conducted in a foreign language and number of applicants for foreign study or training periods.

${ }^{15}$ A direct proportion means that it can be verified from the financial statement of XUAS in a single revenue account. The direct finance means that its provider has a power to decide whether or not to finance XUAS.

16 This payment finances the vocational education system after the comprehensive school. UASs is a part of vocational education system. 
In addition, the municipalities in the area of XUAS own the Municipal Consortium (MC). According to UASs Act (351/2003), the government may grant the operating license for $\mathrm{MC}^{17}$ which enables it to provide UASs-level education. The MC of XUAS is totally owned by 20 municipalities which are located in XUAS area. The proportion of shares for the MC varies between 0.05-49.5 percent among the different municipalities. The municipalities also have the majority of the representatives on the MC board and thus hold the formal decision making authority over XUAS.

Several other public organizations such as a regional hospital district and other public funding agencies provide various forms of support to XUAS. According to XUAS Dean, "We are doing applied research... there are some required projects funded such as for ERDF, ESF or TEKES." The hospital district is important as an employer for graduating students and as a place for student practicums. The hospital district and public funding agencies were important stakeholders primarily in research and development where these organizations provided the majority of income. Another Dean stated, "We are conducting research projects with municipalities and with the [regional] hospital district... The hospital district also hoped [specified] a degree program [to be started]." The annual report shows that these public organizations' provide a relatively low proportion of total XUAS income, however. The head of the hospital district is also a representative on XUAS board.

Local firms also have an official role in supporting UASs. The UASs Act (351/2003) requires including representatives of business and industry on the board of UASs. The local firms fund research projects although the annual report shows their proportion of total XUAS income is quite low. The local firms also have different cooperation forums for teaching in

\footnotetext{
${ }^{17}$ According to the UASs act, the license can be granted also for a municipality, limited liability company or foundation.
} 
XUAS. The Dean commented, "We have different discussions, cooperation forums and research projects with them [local firms].”

Local firms also provide important support to XUAS through student projects.

Students are required to have a practicum and thesis to earn a degree. According to the degree requirements, students can include project studies in their degree program that are conducted with local firms and public organizations. For instance, a project could be constructing a market analysis for local firms.

Of course, students provide a key resource for XUAS success: quality students. Students feel that XUAS attractiveness affects the qualifications of the students and the level of cooperation, as illustrated by the following quote:

"XUAS attractiveness affects what kind of students we will admit to this XUAS. If we have a large number of applicants and we are able to choose the students, the [selected] students are better and have higher motivation. That way the students are more qualified and we can achieve better results" (Secretary-General of XUAS student union).

Students are also a direct source of income for XUAS. According to the Finnish Act of Financing Teaching and Culture (1705/2009), the government pays UASs according to the number of students and graduates. The Act (1705/2009) states that $70 \%$ is paid based on the number of students in the UAS and the other $30 \%$ is paid based on the number of graduates. This payment method was mentioned in several different interviews, including the CFO of XUAS: "The degrees are very important because they drive [nowadays] 30 percent of income [from the government]."

Finally, students organize the tutoring in XUAS. According to XUAS student union website, over 120 volunteer tutors advise, help, and counsel with students during their studies. All XUAS units have a tutor manager who is responsible for organizing tutor activities in a unit in XUAS. 
In summary, the resources provided to XUAS differ among the various stakeholders. The MEC clearly provided the largest amount of financial resources to XUAS, and thus its role as a resource provider is superior. Some stakeholders provide funding for operations but others provide, for instance, opportunities for practicums or theses. The empirical findings for the XUAS are summarized in Table 2, which shows the different the types of resources that each major stakeholder provides, their expectations, and the measures that are important to them. Next, we discuss the key overall measure for XUAS.

\section{[Insert Table 2 about here]}

\subsection{Key measure used at XUAS}

PMS use become very different compared to PMS design in XUAS. The PMS design was balanced in a way taking into account different stakeholders. However, PMS use became very focused around one important measure. In this section, we discuss how attractiveness became the key measure for most of the stakeholders and why.

Almost all interviewed mentioned that to be successful, a XUAS unit must be attractive to a large number of students interested in its degree programs, as indicated by a high ratio of applicants to new students. The written vision of the XUAS strategy states that "XUAS is an attractive XUAS both from the perspectives of students and employees and its finances are stable." The strategy identifies several different critical success factors for four different perspectives. The first critical success factor in XUAS strategy is "high attractiveness in all education." In addition to the strategy, almost all XUAS Deans mentioned the attractiveness of XUAS as the most important factor for XUAS success, particularly in teaching. One Dean commented, "The attractiveness has been emphasized... The target of our stakeholders is definitely attractiveness and it is evaluated [by them]." Another Dean made the following statement: 
"The most challenging [target] is attractiveness both for all XUAS as well as in this XUAS unit... it is an important target because it shows whether we can or cannot attract the students. This attractiveness also affects the other measures such as how they can complete their studies and our financial profit."

In addition to the Deans, the administrative director emphasized the crucial life or death importance of attractiveness as a key measure for XUAS success. ${ }^{18}$

"The greatest challenges are how we can improve XUAS structural reform and attractiveness so that we can succeed in competition... to remain as an existing XUAS" [Administrative director in a published interview]

Attractiveness and its development were also followed and debated in several newspaper articles from spring 2011 to spring 2012.

"Strong variation in the levels of university attractiveness ratios" (Headline in Helsingin Sanomat, a major Finnish newspaper, April 22, 2011).

"UASs of the area are attractive. (Headline) Number of applicants to XUAS increased by over 12 per cent. Number was the highest in the history of the XUAS. Result was both expected and a glad surprise. We are very happy, says the head of the student affairs." (Local newspaper, April 14, 2011).

"XUAS President is relieved that the school living under the shadow of MEC cutting list has not lost its attractiveness. [...] It was a fear that degree programs under the threat of closing have faced big changes, but it didn't happen. [...] We have to act in a way that viable degree programs can continue, states XUAS President directing the decisions." (Local newspaper, April 26, 2012)

Attractiveness was even called a "super measure" in different interviews. The level of this measure was discussed in different internal and external meetings. The attractiveness ratio was discussed in target negotiations with MEC and internally in steering groups and

\footnotetext{
${ }^{18}$ For the R\&D area, XUAS has a different target than attractiveness. The primary target of R\&D is financial income and especially EBITDA. XUAS President commented, "In the R\&D profit center ... the financial income target relating to EBITDA is important." XUAS Research and development director and a dean emphasized the importance of external financing as an important measure in R\&D. Some interviewed mentioned also the importance of balanced budget as an important measure in the following quotation: "Naturally, financial measures are important. We get budget numbers monthly from CFO... how much we have spent [money] and how much [money] we have remaining so that the [budget] is balanced" (A dean). When another dean was asked about the key measures he is controlling, he replied, "I'm controlling financial issues and attractiveness measures."
} 
meetings for employees. ${ }^{19}$ The target negotiations with MEC are important because the MEC decides the number of students—-which drives the majority of XUAS income-and programs after these discussions.

"These attractiveness ratios, number of education programs and their size are considered [during target negotiations with MEC]... [the MEC] actually asks, 'Do you need this program because the number of applicants [i.e. attractiveness] is so [low in this program]?' (Chairman of Board of MC \& Vice Member of board of the largest city in XUAS area).

"Super measure is evaluated in target negotiations with MEC. Super measure is attractiveness" (Manager of student placement)

"In our internal target negotiations the attractiveness ratio is emphasized. I feel in that way. It might be that there are also other measures but this measure is it [most important]" (Dean of XUAS)

We observed several reasons why attractiveness became such an important key

measure for XUAS. First, the MEC perceived serious inefficiencies in UASs system. In 40 of 170 degree programs, the average attractiveness ratio less than 1.5 (i.e., less than 1.5

applicants per new student) (Salminen and Ylä-Anttila, 2010). In addition, according to MEC statistics, some universities of applied sciences had overall attractiveness ratios less than 2.0. Achieving attractiveness targets has been the hardest goal to achieve for XUAS. Because attractiveness has been low and below the target, it constitutes one of the biggest challenges and threats for XUAS.

To address the perceived inefficiencies, the MEC launched its structural development program to increase average UASs size and decrease the number of units in UASs. UASs attractiveness and effectiveness in resource utilization became two indicators used to compare Finnish UASs and measure success in the structural development program. Attractiveness was considered the best way to measure and compare performance among the

\footnotetext{
${ }^{19}$ During observation in several internal meetings for employees, we found that almost all of them explicitly showed the ratios for attractiveness and number of applicants.
} 
various units to help decide which units to close or merge. And XUAS's high dependency on the MEC for funding enables the MEC to determine the key measure for XUAS.

A second reason for attractiveness being the key measure is the imbalance between educational demand and supply. UASs educational demand may be decreasing for the future based on Statistics Finland, which reports a 15\% decrease in the birth rate from 1990 to 2002. On the other hand, UASs cost per student has increased over 20\% from 2006 to 2010 (FNBE, 2010, p. 6). The increased costs of education have been reported by MEC's structural development program, which states that "improving [operational] efficiency requires changes in the operational environment when [UASs] are developed." Thus, reducing educational costs became very important for the whole system, and attractiveness provides a way of determining the efficiency of UASs programs.

Third, there were a number of students who do not graduate within the target period of time, or worse, never graduate. Both issues have led to increasing "waste" in the education system (Salminen and Ylä-Anttila, 2010). Attractiveness has a statistically significant positive correlation with the graduation success and a negative correlation with the ratio of students not graduating, known as the "wastage ratio" (Pääkkönen, 2010). According to Pääkkönen $(2010,43)$, “The lower-motivated students get placed in a less attractive universities in UASs with less attractive degree programs. The lower-motivated students waste their studies more frequently than other students" (Pääkkönen, 2010, 43).

Fourth, the municipalities wanted to retain XUAS campuses in their municipality district. This desire has at least partly contributed to the fragmentation in the UASs educational system. MEC could not by itself directly close any UASs university or its subunits, but it was able to force closures by allocating fewer financial resources. This relationship is described in the following citation:

"Decisions concerning the XUAS units are done locally, and we have to accept that in the MEC at least so far. ... MEC wishes that XUAS units will not just wait 
for a slow death, but accelerate the development." (Director of Higher Education and Science, Local Newspaper, May 12, 2011)

Part of this allocation decision was based on incentives paid to "successful" UASs units. Success was typically defined based on attractiveness, driven by the ability of UASs to make structural changes (unit closures or removal to a central city area). Attractiveness became the single most important criteria and key indicator of success in XUAS because the local municipalities were unlikely to make any structural changes due to the fact that they wanted to retain XUAS units in their own municipality.

A fifth important reason for attractiveness becoming the key indicator is its importance to students. It is important to students because it measures the preferences of young people concerning subjects, area of education, location, and even UASs itself (Pääkkönen, 2010). Our stakeholder analysis revealed that both students and local firms recognized the relation between improved attractiveness and the qualifications of students coming out of XUAS.

In summary, three primary stakeholders-MEC, municipalities, and students—have had considerable impact on why attractiveness is a key XUAS target. Figure 3 illustrates the process of how attractiveness became the most important indicator and what kinds of outcomes were associated with improvement on this key indicator. Municipalities wanted to retain their XUAS units and MEC wanted to restructure the fragmented and inefficient UASs educational system. The core of this conflict was the financial arrangement in which the payments of municipalities to the MEC are reallocated to different XUAS units by the MEC. This arrangement increased XUAS resource dependency on the MEC and enabled the MEC to determine the key indicator for XUAS. Focusing on and improving attractiveness provided several observed outcomes, including more qualified students, improved efficiency and less 
waste, more desirable programs to attract students to XUAS, substantial economic impact to cities losing XUAS units, and increased migration of young people to larger cities.

\section{[Insert Figure 3 about here]}

\section{Discussion}

In this section, we discuss the findings of this study in relation to the original research question, the PMS literature, and the related theories. First, we discuss how stakeholder theory helps explain the impact of various stakeholder interests on PMS design. Second, we explain how resource dependency theory helps explain which measures are used for decision making. Third, we suggest some implications of not including some stakeholders' interests in the selection of the key target measures. Finally, we discuss why the key measure for a public sector organization is nonfinancial rather than financial and why this matters.

\subsection{Stakeholder interests in PMS design and use}

SHT predicts that different stakeholders have different expectations of an organization, and we observed that these expectations translated into different targets in the PMS design such as proposed in the framework of Ferreira and Otley (2009). This study finds both competing and congruent expectations among stakeholders (Collier, 2008). An example of competing interests is that municipalities would like to retain all the small XUAS units in their municipality whereas the MEC wanted larger XUAS units. Congruent interests include both the municipalities and the ministry expecting the UAS to be attractive and able to cooperate with local firms.

As suggested by the theoretical model illustrated in Figure 1 and exemplified by Figure 3 for the case organization, the result of the varied and sometimes conflicting stakeholder interests is a balanced scorecard design consisting of a large number (18) of different measures (see Tables 1 and 2). Although SHT explains well the PMS design, 
resource dependency theory better explains PMS usage. The varied expectations were made more congruent because the battle for survival of XUAS and its units was based on attractiveness. The stakeholder with dominant financial resources looked at attractiveness as a key indicator in monitoring XUAS. In order to survive, the XUAS and its units were forced to monitor the same measure and make efforts to increase attractiveness in several ways.

The conflicting interests between stakeholders seem to be balanced in the PMS design when the interests were turned into explicit targets (see Sundin et al., 2010). However, although the interests seem to be balanced in PMS design, they were not balanced in actual PMS use. The interviews consistently identified attractiveness as a key or "super" target in PMS use. The results show clearly that PMS design and PMS use are two very different phases and concepts (e.g. Ferreira and Otley, 2009) and the variability of the stakeholders' interests is much easier to observe in the PMS design phase. Together, this study contributes to earlier SHT studies in the PMS domain by showing that despite conflicting interests among various stakeholders in the PMS design, the key target used was congruent among all stakeholders.

\subsection{Impact of resource dependency on key measure used}

Resource dependency theory helps explain how a few primary stakeholders can impact the selection of the key target measure in use. Consistent with our theoretical model (see Figures 1 and 2), the dependency of XUAS on its largest financial resource provider (MEC) became a filter that greatly affected XUAS strategy and key measure. MEC became the largest resource provider when it had power to allocate financial resources from both government and municipalities to the different universities in UASs. The dependency of the XUAS on these resources enabled the MEC to make attractiveness the leading performance indicator in PMS use. 
However, other stakeholders besides the MEC also mentioned extensively the importance of XUAS attractiveness. It is understandable that the internal stakeholders (such as UAS deans and managers) of XUAS mentioned this measure launched by the MEC because they are also directly controlled by this key resource provider. The surprising issue is that external stakeholders also mentioned this same measure as a key target in their interviews. One reason might be that media attention given to the threat of decreasing the number of UASs or closing the XUAS units has impacted other stakeholders also. Other stakeholders recognize the closure threat as a political constraint when they considered key targets (see more from Li and Tang, 2009). Another reason might be the expected outcomes of that key measure. Attractiveness was considered important for improving the efficiency of UASs educational system, teaching quality and helping ensure qualified employees for local firms.

These findings indicate that the key resource provider was able to institutionalize (e.g., Burns and Scapens, 2000) this measure (attractiveness) into the realm of XUAS and its stakeholders. These results are consistent with Pfeffer and Salancik (2003, pp. 46-47, 259) who propose that stakeholder control over an organization is affected by its resource criticality and scarcity. Someone may consider it unsurprising that the stakeholder providing the most resources had the highest impact on PMS use. The surprising issue was that all stakeholders, regardless of amount of resources provided, mentioned the same key target. Thus, it may be that the key resource provider also has some impact on the expectations of other stakeholders. Therefore, the stakeholder with the most resources may have two different roles in PMS use: (1) it can force elimination of the conflicting interests between the stakeholders (i.e. filter in Figure 1 and 2), and (2) it may impact the expectations of other stakeholders. In summary, this study contributes to earlier PMS studies by combining RDT and SHT, as supported by Christopher (2010) and Hillman et al. (2009). 


\subsection{Implications of excluding some stakeholders' interests}

As proposed by the theoretical model, the filtering of various scorecard measures into a key measure based on resource dependency led to some desired outcomes for most stakeholders (see Figure 3). Focusing on attractiveness increases the level of qualifications required for students, leading to more qualified graduates for municipalities and local firms. It also helped to improve graduation rates and efficiency (i.e., less waste) by measuring student preferences and placing more motivated and qualified students in XUAS units with more attractive degree programs. Thus, less motivated students get weeded out.

However, there are also less desirable consequences for some stakeholders by not including their goals in the key target measures used for decision making. Stakeholders with competing interests not congruent with the primary resource provider or the key target measure may not achieve those goals. This was particularly observed in restructuring situations where less-attractive XUAS units and programs were either closed down or moved to other (usually larger) cities. The economic impact to the city is substantial for several reasons, such as fewer employees available to local firms in these cities, higher unemployment in these cities due to education being more difficult to obtain, less qualified students for R\&D projects in those areas, and increased migration of young people to other cities. These issues make the municipality less attractive to qualified employees and potential students due to fewer educational academic programs. If the programs are not attractive, they will be phased out. Thus, another consequence is fewer program choices for students.

Excluding some stakeholders' goals from the primary measures used also added tension within XUAS organization. Particularly those XUAS units which had a low value in one key ratio tried to prioritize and show their success in other ratios (e.g., employment rate or external finance) or the general importance of a specific program (e.g., demand in future, national or local importance). The purpose of these attempts was to question the validity of 
the key measure and provide alternative key measures. However, this criticism was effectively eliminated by the key stakeholder who forced the closure of XUAS units with the lowest attractiveness ratios, resulting in many employee lay-offs.

The less desirable consequences of XUAS closures have implications for SHT. Stakeholders whose requirements are fulfilled in the PMS design but effectively ignored in PMS usage tried to affect the selection of a key measure as long as possible. The tension between XUAS units (and their location cities) relating to successful and unsuccessful attractiveness was highly visible (e.g., in local newspapers) as a political issue. Because of these tensions, some compromises should have been made between the units in closing some degree programs to balance the situation, but were not. These consequences present a challenge to the implementation of SHT, which argues that the utility of a large number of different stakeholders, including shareholders, is maximized when the firm strives to integrate stakeholder needs through multiple objectives (Christopher, 2010; see also Freeman et al., 2004). If competing interests are filtered out by resource dependency on primary stakeholders, satisfying the utility of many stakeholders will be difficult at best.

\subsection{Why the key measure is nonfinancial}

Finally, we discuss why the key measure for a public sector organization is nonfinancial rather than financial and why this matters. This finding was surprising because the importance of nonfinancial measures was not assumed in the lights of value maximization theories (Jensen, 2001). According to these theories, all stakeholders' interests are taken into account sufficiently by maximizing profit. The nonfinancial measure (i.e. attractiveness) became extremely important and the one single leading indicator (Kaplan and Norton, 1996) for all stakeholders as well as for corporate and unit-level managers to use. Public organizations may focus more on nonfinancial indicators for organizational control or achieving their mission than private companies. However, in this case, attractiveness was a 
major leading indicator because it leads both directly and indirectly to better financial results (i.e., payments based on number of students, number of degrees, result-based incentive fees, and the restructurings of XUAS units). Thus, although financial results are the ultimate lagging indicators, certain nonfinancial targets can become the key measure for an organization due to its recognized impact on financial outcomes.

The finding that the key performance measure used for decision making can be nonfinancial if it is a key driver of financial outcomes may have implications for firms pursuing a more balanced approach to performance measurement. In the balanced scorecard approach, financial measures serve as the focus for all of the other nonfinancial perspectives and measures. According to Kaplan and Norton (1996, p. 47), "every measure selected should be part of a link of cause-and-effect relationships that culminate in improving financial performance." If there is one key nonfinancial measure that drives financial outcomes, organizations may feel more comfortable focusing on that measure because they know it will lead to stronger financial results. If there is not one key nonfinancial measure, but several nonfinancial measures as part of the cause-and-effect chain leading to financial results, firms may find it easier to focus on financial measures as the ultimate target measures. This idea may help explain the emphasis on financial measures in firms using a balanced scorecard approach found in previous studies (Kraus and Lind, 2010).

\section{Conclusions}

In this study, we investigate the difference between PMS design and use by investigating stakeholders' effect on the performance measurement system (PMS). Generally, our results indicate that PMS design and PMS use are two very different phases and concepts (e.g. Ferreira and Otley, 2009). The conflicting interests between stakeholders were balanced in PMS design when the interests were turned into explicit targets. However, although the interests became balanced in PMS design (like Sundin et al. (2010) predicted), they were not 
so balanced in actual PMS use. Instead of conflicting interests resulting in multiple key targets in PMS use, one nonfinancial indicator-attractiveness-became the most important key target in PMS use. Resource dependency helped to explain how a few primary stakeholders impact the selection of the key target measures used.

Attractiveness, or the number of applicants per number of new students, became the most important key target. This finding adds to Kraus and Lind (2010) which found that corporate level control was primarily financially-focused in Swedish companies. It may be that public organizations focus more on nonfinancial indicators than profit-oriented firms due to their nonprofit mission. However, attractiveness was also a major leading indicator for better financial results and, moreover, it was a crucial for the survival of XUAS and its units due to the threat of closures or mergers by the MEC. Thus, although financial results may be the ultimate lagging indicators, certain nonfinancial targets can become the key measures for an organization in PMS use due to its impact on financial outcomes or even on its existence. Furthermore, the analysis shows that one "super" nonfinancial measure was able to balance differing stakeholder objectives. Future studies could identify other contexts where nonfinancial measures are the key targets, especially in for-profit firms.

This study differs from earlier PMS studies with SHT by developing a theoretical model that suggests resource dependency acts as a "filter" in selecting certain measures as primary from all the stakeholder-driven measures in the PMS use. Combining stakeholder theory and resource dependency theory with the results of this and previous case studies, we propose the theoretical model illustrated in Figure 1 and exemplified by Figure 3 for the case organization. This filtering leads to both desirable and undesirable consequences for stakeholders and the organization. Those stakeholders with goals not congruent with the primary resource providers or key measures are less likely to achieve those goals. It can also add to the risks that could threaten the long-term viability of XUAS itself. We recommend 
testing the potential of this framework with wider empirical evidence through fieldwork or statistical analysis to test how these outcomes differ in for-profit settings. Perhaps a key customer or market segment that provides the most profits for a firm serves as the primary resource provider and drives the key measures used.

The results of the study have two theoretical implications. First, the expectations of stakeholders need to be identified as proposed by SHT and translated into specific performance indicators in the design of PMS as illustrated in our model. The inclusion of different indicators in the PMS design enables organizations to show they are cognizant of the specific expectations of different stakeholders. This inclusion may improve the feeling among stakeholders that their expectations are considered when PMS are used. Second, it may be possible to predict the use of PMS by combining SHT and RDT theories as presented in our model. By using this model, the most important critical success factor(s) for success and survival of a public sector organization may be identified. These "rules of the game" are set by the major resource provider and recognized by the other stakeholders. The model calls this phenomena "filtering."

In addition to the theoretical model, this study differs from earlier PMS studies using stakeholder theory. According to the results, although the interests of stakeholders may differ, performance measurement and management may still have a single key objective. This partly contradicts earlier studies such as Li and Tang (2009) who proposed that "stakeholder theory fails to provide corporate managers with a single objective." SHT illustrated why PMS design has many and sometimes conflicting measures. However, the finding of a single key objective is consistent with the suggestion of Jensen (2001) that purposeful action requires a single valued objective function. In this study, the objective function consisted of one variable: attractiveness. 
An alternate explanation for why the key XUAS objective was balanced between stakeholders may be that XUAS was owned by municipalities. Sundin et al. (2010) found that a state-ownership structure may have led to balanced objectives in their case company. However, the ownership structure of XUAS is somewhat different because the MEC is not an "owner" of XUAS although it pays the largest amount of XUAS financial resources and holds a dominant gatekeeper position for those resources. On the other hand, the MEC is also able to affect UASs by other modes of control such as by legislation. Therefore, this study extends the findings of Sundin et al. (2010). Although municipalities own XUAS and their interests often conflict with each other (e.g., each wants to have XUAS unit in their municipality), the overriding objective (XUAS attractiveness) can still be similar.

Finally, we find specific resource dependencies and collected empirical data to support the idea that both internal and regulatory stakeholders have impact on the KPI, which is consistent with Darnall et al. (2009). Contrary to Darnall et al. (2009), however, we find that an external, regulatory stakeholder (i.e., MEC) had the most impact on the selection of a KPI and probably also the expectations of other stakeholders. This same KPI was mentioned by other stakeholders such as students and municipalities. Darnall et al. (2009) suggests that internal stakeholders have the most impact on KPI selection. However, the Darnall et al. (2009) study focuses on environmental issues in private manufacturing firms as opposed to this study which focuses on PMS issues in a public non-manufacturing organization.

The results of this study should be considered in light of certain limitations. First, the impact of stakeholders on public sector organizations might be very different than that for private sector organizations with for-profit objectives. Future studies could test whether primary targets are always financial and which stakeholders besides shareholders have the most influence on key targets in for-profit organizations. Second, we applied a longitudinal qualitative single case study method which does not allow for statistical analysis. This 
limitation suggests the need for more studies with quantitative methods for more generalizable results. Third, PMS are only one component of the overall management control system. An interesting issue for future studies would be how stakeholders affect wider management control system (MCS) patterns (Kamminga and Van der Meer-Kooistra, 2007) in addition to PMS design and PMS use.

Although this study is limited to a single case organization, it identifies stakeholders and their expectations in more detail than earlier studies (e.g. Atkinson et al., 1997; Kraus and Lind, 2010; Li and Tang, 2009; Sundin et al., 2010). The major finding and contribution of the study is that the conflicting interests of stakeholders do not automatically lead to a large number of key indicators used in decision making, which contradicts the basic proposition of stakeholder theory. We propose a theoretical model suggesting that the process of selecting key nonfinancial indicators is complex. The resources supplied by stakeholders can significantly impact which measures are focused on. We hope future PMS research will test this theoretical model and find it helpful. 
Figure 1. Theoretical framework for the study

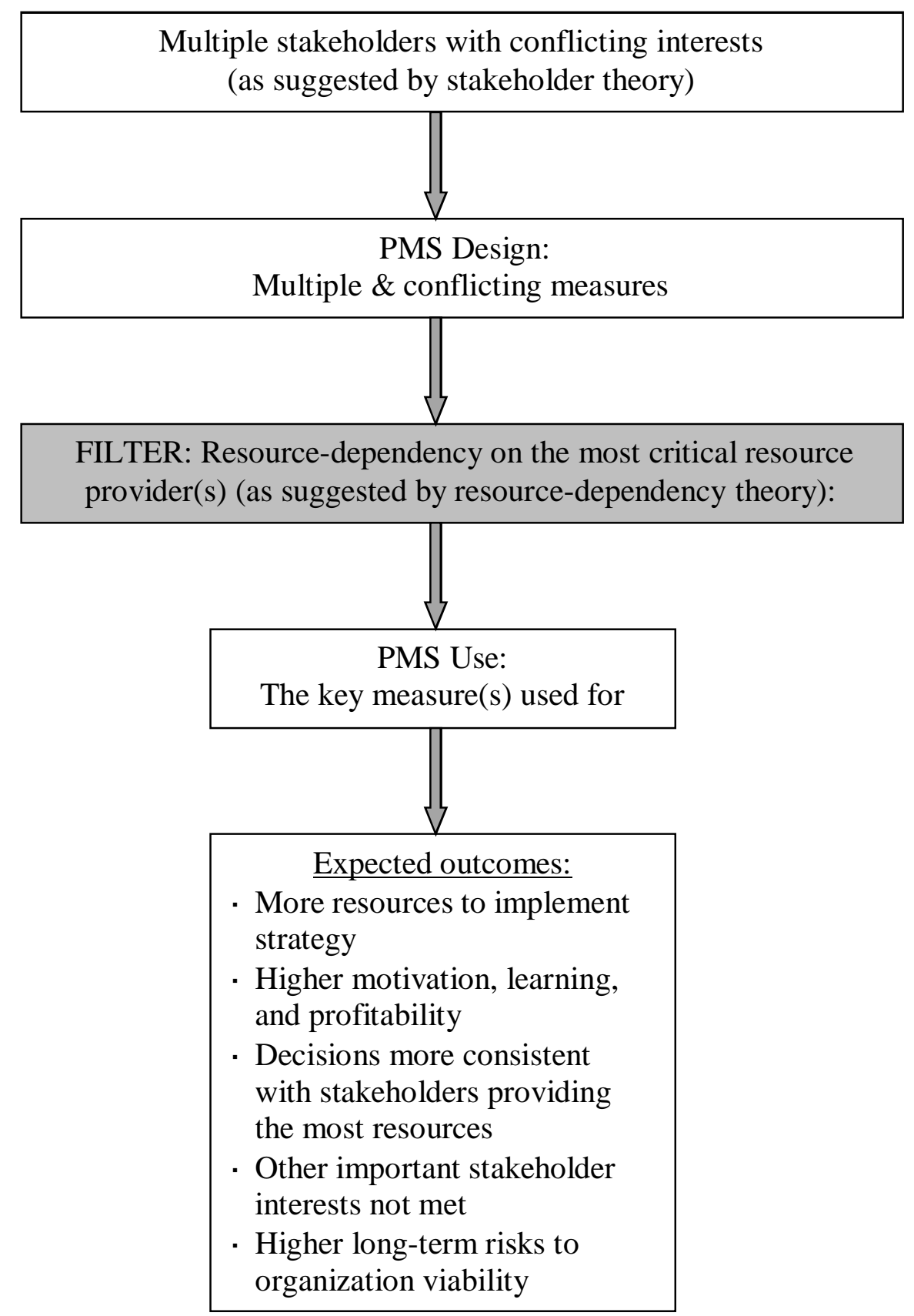


Figure 2. Municipalities (A) direct and (B \& C) indirect finance

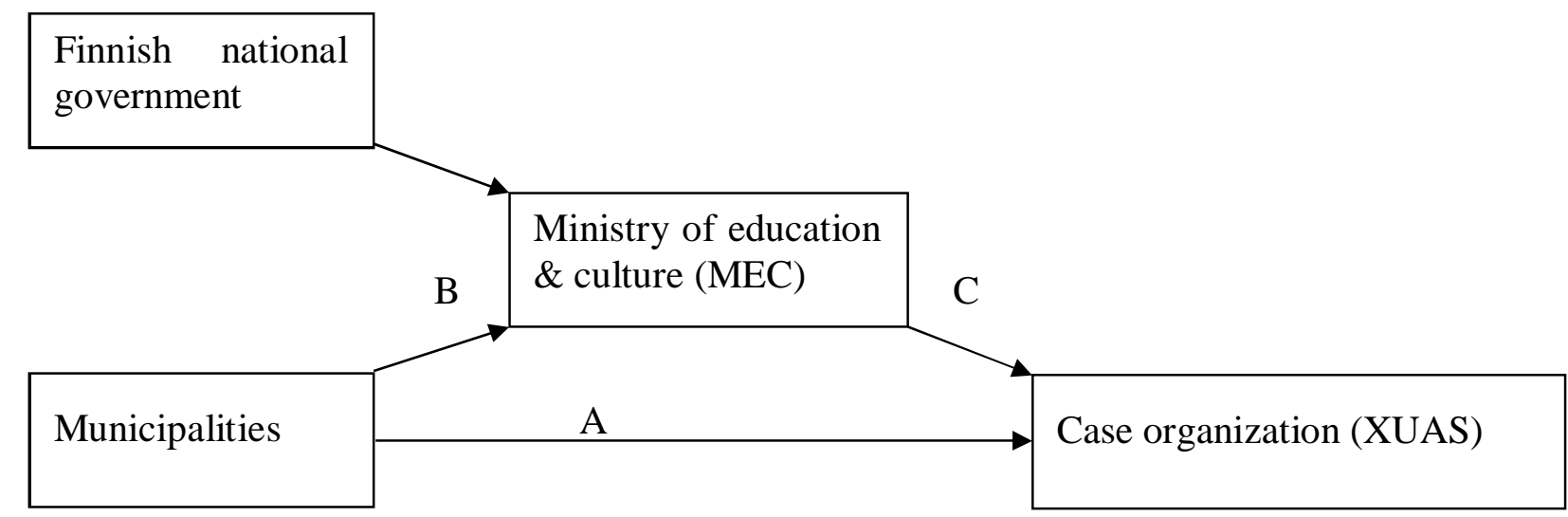


Figure 3. Forces for the selection of a key target and expected outcomes

Stakeholders: MEC, municipalities, students, local firms, and other public organizations

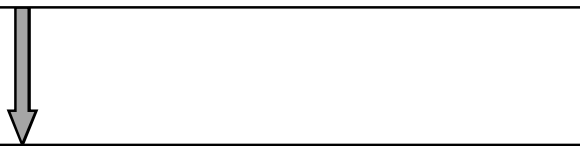

PMS Design: Reflect conflicting interests such as

- MEC: restructure fragmented UAS to be more efficient

- Municipalities: retain UAS units in municipality

- Students: desirable programs

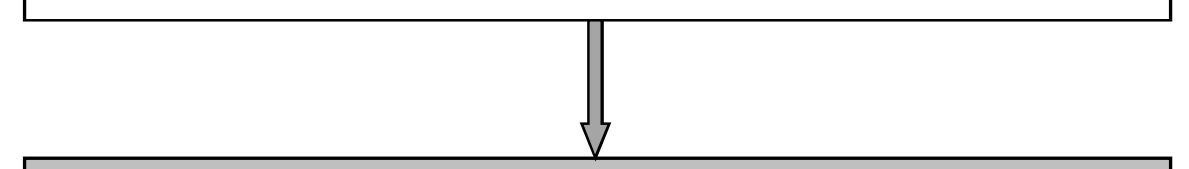

FILTER: Resource dependency

- Municipalities pay taxes to MEC

- MEC reallocates funds to different units in UASs (increasing resource dependency on MEC)

- MEC starts Structural Development Program which relies on attractiveness as a key driver for resource allocation

$\left.\begin{array}{|l||}\hline \frac{\text { Key Measure: UAS Attractiveness }}{\text { No. of student applicants }} \\ \text { No. of new students }\end{array}\right]$


Table 1. PMS design in case organization

\begin{tabular}{|c|c|c|c|}
\hline Critical success factor & Indicator & $\begin{array}{l}\text { Target*: } \\
\text { Unit level }\end{array}$ & $\begin{array}{l}\text { Target*: } \\
\text { UAS level }\end{array}$ \\
\hline \multicolumn{4}{|l|}{ 1. Customers } \\
\hline -Attractiveness in all education programs & Number of applicants $\div$ by number of new students & $\mathrm{X}$ & $\mathrm{X}$ \\
\hline -Satisfied, well-motivated and committed students & Drop outs & $\mathrm{X}$ & $\mathrm{X}$ \\
\hline -Internationally known and wanted XUAS for foreign students & Student satisfaction & $\mathrm{X}$ & $\mathrm{X}$ \\
\hline -Students' capabilities and orientation for entrepreneurship & Entrepreneurship of students & $\mathrm{X}$ & $\mathrm{X}$ \\
\hline -Professional skills and employment of graduated students & Employment Rate & $\mathrm{X}$ & $\mathrm{X}$ \\
\hline -Leading role as an innovator in XUAS area & RDI awareness & $\mathrm{X}^{* *}$ & $\mathrm{X}$ \\
\hline \multicolumn{4}{|l|}{ 2. Processes } \\
\hline -Qualified and profitable teaching & EBITDA in teaching and RDI & $\mathrm{X}$ & $\mathrm{X}$ \\
\hline -Qualified and profitable RDI & External finance of RDI & $\mathrm{X}$ & $\mathrm{X}$ \\
\hline -Establishment of quality work & Achievements in key processes & $\mathrm{X}$ & $\mathrm{X}$ \\
\hline -Systematic prediction of a new teaching possibilities & Not defined & $\mathrm{X}^{* *}$ & No \\
\hline \multicolumn{4}{|l|}{ 3. Employees } \\
\hline -Motivating atmosphere for own knowledge capabilities & Number of education days per employee & $\mathrm{X}$ & $\mathrm{X}$ \\
\hline -Supporting own knowledge and spirit of entrepreneurship & Work development & $\mathrm{X}$ & $\mathrm{X}$ \\
\hline -Welfare of employees & Satisfaction of employees & $\mathrm{X}$ & $\mathrm{X}$ \\
\hline \multicolumn{4}{|l|}{ 4. Owners (financier) } \\
\hline -Regional balance in education and RDI with national targets & Qualitative assessment: MEC feedback \& Stakeholders' panel & $\mathrm{X}^{* *}$ & No \\
\hline -Responding to the knowledge requirements in area & Employment in region & $\mathrm{X}$ & $\mathrm{X}$ \\
\hline \multicolumn{4}{|l|}{ 5. Partners } \\
\hline -Improving co-operation with universities in the region & Project and teaching co-operation with strategic partners & $X^{* *}$ & No \\
\hline -Essential role in regional internationalization by int. partners & Number of international students & $\mathrm{X}$ & $\mathrm{X}$ \\
\hline -XUAS co-operation in strategic priorities & Number of co-operation agreements in prioritized areas & $\mathrm{X}^{* * * *}$ & $\mathrm{X}$ \\
\hline
\end{tabular}


Table 2 Summary of stakeholders, their expectations, resources and linkage to key performance measure in PMS design

\begin{tabular}{|c|c|c|c|}
\hline Stakeholder & Stakeholder resources & Stakeholders expectations & Key Performance Measures \\
\hline \multicolumn{4}{|l|}{ External stakeholders: } \\
\hline Ministry (MEC) & $\begin{array}{l}\text { - Financial (over } 75 \% \text { of UAS } \\
\text { budget. Over } 50 \% \text { of that is } \\
\text { collected from municipalities and } \\
\text { less than } 50 \% \text { from government) }\end{array}$ & $\begin{array}{l}\text { - } \text { Attractive and efficient degree } \\
\text { programs } \\
\text { - Large XUAS } \\
\text { - Renewal capability of XUAS }\end{array}$ & $\begin{array}{l}\text { - Attractiveness in all education } \\
\text { programs } \\
\text { - Drop outs, employment rate } \\
\text { - MEC qualitative feedback }\end{array}$ \\
\hline Municipalities & $\begin{array}{l}\text { - Financial (both directly and via } \\
\text { MEC) } \\
\text { - Securing loans for XUAS }\end{array}$ & $\begin{array}{l}\text { - Attractive municipality } \\
\text { - XUAS located in municipality } \\
\text { - Prevent young adult movement to } \\
\text { other cities } \\
\text { - Qualified employees for local firms }\end{array}$ & $\begin{array}{l}\text { - Attractiveness in all education } \\
\text { programs } \\
\text { - Employment in region } \\
\text { - External finance of RDI }\end{array}$ \\
\hline Local firms & $\begin{array}{l}\text { - Opportunities for student theses and } \\
\text { practicums } \\
\text { - Financial resources (esp. for R\&D) }\end{array}$ & $\begin{array}{l}\text { - Qualified employees for local } \\
\text { companies } \\
\text { - R\&D projects } \\
\text { - Customized education }\end{array}$ & $\begin{array}{l}\text { - Attractiveness in all education } \\
\text { programs } \\
\text { - Employment in region } \\
\text { - RDI awareness RDI EBITDA }\end{array}$ \\
\hline $\begin{array}{l}\text { Other public organizations } \\
\text { (ERDF, ESF, TEKES) }\end{array}$ & - R\&D funding & $\begin{array}{l}\text { - Qualified R\&D projects } \\
\text { - Promoting economic \& social } \\
\text { development }\end{array}$ & $\begin{array}{l}\text { - RDI awareness } \\
\text { - EBITDA in teaching and RDI } \\
\text { - External finance of RDI }\end{array}$ \\
\hline \multicolumn{4}{|l|}{ Internal stakeholders: ${ }^{20}$} \\
\hline Students & $\begin{array}{l}\text { - } \text { MEC funding is based on number of } \\
\text { students \& degrees awarded } \\
\text { - Employees for R\&D projects } \\
\text { - Tutoring new students }\end{array}$ & $\begin{array}{l}\text { - Attractive \& enjoyable city } \\
\text { - Teaching quality } \\
\text { - Desirable programs }\end{array}$ & $\begin{array}{l}\text { - Attractiveness in all education } \\
\text { programs } \\
\text { - Drop outs, Student satisfaction, } \\
\text { Employment rate }\end{array}$ \\
\hline
\end{tabular}

\footnotetext{
${ }^{20}$ XUAS Deans considered other Deans of XUAS as important stakeholders. The deans expected that XUAS should be attractive for the students. The results indicate the key resource for them was benchmarking other XUAS units and XUAS unit meetings.
} 


\section{Appendix: Individuals interviewed for this study}

\begin{tabular}{|c|c|c|c|}
\hline Position & Date & $\begin{array}{l}\text { Duration of } \\
\text { record }\end{array}$ & $\begin{array}{l}\text { Recording }(R e) \& \\
\text { transcribed }(T r)\end{array}$ \\
\hline \multicolumn{4}{|l|}{ Preliminary interviews } \\
\hline Dean (School of technology) & 11. Aug 2008 & 1.5 hours & Field notes \\
\hline Quality officer of the unit (Business school) & 11. Aug 2008 & 1 hour & Field notes \\
\hline Vice President of XUAS & 12. Aug2008 & 1 hour & Field notes \\
\hline Development manager of XUAS & 14. Aug 2008 & 1.5 hours & Field notes \\
\hline Dean (Business school) & 14. Aug 2008 & 1.5 hours & Field notes \\
\hline Secretary-General of XUAS student union & 14. Aug 2008 & 1 hour & Field notes \\
\hline \multicolumn{4}{|l|}{ Follow-up semi-structured interviews } \\
\hline Headquarter level & & & \\
\hline President of XUAS ${ }^{\mathrm{a}}$ & 24. May 2010 & $53 \min$ & $\operatorname{Re} \& \operatorname{Tr}$ \\
\hline Vice president of XUAS & 17. Aug 2010 & $68 \min$ & $\operatorname{Re} \& \operatorname{Tr}$ \\
\hline Research and development director of XUAS & 17. Aug 2010 & $75 \mathrm{~min}$ & $\operatorname{Re} \& \operatorname{Tr}$ \\
\hline Administrative director of XUAS ${ }^{a}$ & 24. May 2010 & $53 \mathrm{~min}$ & $\operatorname{Re} \& \operatorname{Tr}$ \\
\hline Chief financial officer (CFO) of XUAS & 9. Aug 2010 & $47 \mathrm{~min}$ & $\operatorname{Re} \& \operatorname{Tr}$ \\
\hline Quality manager of XUAS & 19. Aug 2010 & $63 \min$ & $\operatorname{Re} \& \operatorname{Tr}$ \\
\hline Development manager of XUAS & 22. Aug 2010 & $103 \mathrm{~min}$ & $\operatorname{Re} \& \operatorname{Tr}$ \\
\hline IT manager of XUAS & 11. Aug 2010 & $75 \mathrm{~min}$ & $\operatorname{Re} \& \mathrm{Tr}$ \\
\hline Manager of student placement & 13. Sept 2010 & $59 \min$ & $\operatorname{Re} \& \operatorname{Tr}$ \\
\hline \multicolumn{4}{|l|}{ Faculties of XUAS } \\
\hline Dean (School of technology) & 16. Aug 2010 & $103 \mathrm{~min}$ & $\operatorname{Re} \& \operatorname{Tr}$ \\
\hline Dean (School of health care and social work) & 26. Aug 2010 & $56 \mathrm{~min}$ & $\operatorname{Re} \& \operatorname{Tr}$ \\
\hline Dean (School of agriculture and forestry) & 16. Aug 2010 & $64 \mathrm{~min}$ & $\operatorname{Re} \& \operatorname{Tr}$ \\
\hline Dean (School of Culture and design) & 24. Aug 2010 & $63 \mathrm{~min}$ & $\operatorname{Re} \& \operatorname{Tr}$ \\
\hline Dean (Business school) & 11. Aug 2010 & $95 \mathrm{~min}$ & $\operatorname{Re} \& \operatorname{Tr}$ \\
\hline Principal lecture \& ex-dean (Business School) & 19. Aug 2010 & $83 \mathrm{~min}$ & $\operatorname{Re} \& \operatorname{Tr}$ \\
\hline \multicolumn{4}{|c|}{\begin{tabular}{l|l|l} 
Others & I . nug 2010 \\
\end{tabular}} \\
\hline Minister of the Finnish government & 25. Oct 2010 & $54 \mathrm{~min}$ & $\operatorname{Re} \& \operatorname{Tr}$ \\
\hline $\begin{array}{l}\text { Mayor of the largest municipality in XUAS } \\
\text { the area }\end{array}$ & 27. Aug 2010 & $62 \mathrm{~min}$ & $\operatorname{Re} \& \operatorname{Tr}$ \\
\hline $\begin{array}{l}\text { CEO of The Regional Organization of } \\
\text { Enterprises in XUAS area }\end{array}$ & 29. Oct 2010 & $61 \mathrm{~min}$ & $\operatorname{Re} \& \operatorname{Tr}$ \\
\hline $\begin{array}{l}\text { The director of education in the ministry of } \\
\text { education and culture (MEC) }\end{array}$ & 30. Sept 2010 & $80 \mathrm{~min}$ & $\operatorname{Re} \& \operatorname{Tr}$ \\
\hline $\begin{array}{l}\text { The chairman of board of municipal } \\
\text { consortium (MC) of XUAS \& The vice } \\
\text { member of board of the largest city in XUAS } \\
\text { area }\end{array}$ & 27. Aug 2010 & $79 \min$ & $\operatorname{Re} \& \operatorname{Tr}$ \\
\hline Secretary-general of XUAS student union ${ }^{\mathrm{b}}$ & 13. Oct 2010 & $77 \mathrm{~min}$ & $\operatorname{Re} \& \operatorname{Tr}$ \\
\hline Chairman of XUAS student union ${ }^{\mathrm{b}}$ & 13. Oct 2010 & $77 \mathrm{~min}$ & $\operatorname{Re} \& \operatorname{Tr}$ \\
\hline $\begin{array}{l}\text { A business school student in XUAS } \\
\text { a, b }\end{array}$ & 13. Oct 2010 & $77 \mathrm{~min}$ & $\operatorname{Re} \& \operatorname{Tr}$ \\
\hline
\end{tabular}




\section{References}

Abernethy, M. A., and Chua, W. F., 1996. A field study of control system "redesign": The impact of institutional processes on strategic choice. Contemporary Accounting Research 13 (2), 569-606.

Ackermann, K., Eden, C., 2011. Strategic Management of Stakeholders: Theory and Practice. Long Range Planning 44 (3), 179-196.

Arnaboldi, M., Azzone, G. (2010) Constructing performance measurement in the public sector. Critical Perspectives on Accounting 21 (4), 266-282.

Atkinson, A.A., Waterhouse, J.H., Wells, R.B., 1997. A Stakeholder Approach to Strategic Performance Measurement. Sloan Management Review 38 (3), 25-37.

Ax, C., Bjørnenak, T., 2005. Bundling and diffusion of management accounting innovations - the case of the balanced scorecard in Sweden. Management Accounting Research 16 (1), 1-20.

Broadbent, J., Guthrie, J., 2008. Public Sector to Public Services: 20 Years of "Contextual" Accounting Research. Accounting, Auditing and Accountability Journal 21 (2), 129169.

Burns, J. and Scapens, R.W., 2000. Conceptualizing management accounting change: An institutional framework. Management Accounting Research 11 (1), 3-25.

Camara, M., Chamorro, E., Moreno, A., 2009. Stakeholder Reporting: The Spanish Tobacco Monopoly (1887-1986). European Accounting Review 18 (4), 697-717.

Christopher, J., 2010. Corporate governance - A multi-theoretical approach to recognizing the wider influencing forces impacting on organizations. Critical Perspectives on Accounting 21 (8), 683-695.

Collier, P.M., 2008. Stakeholder accountability: A field study of the implementation of a governance improvement plan. Accounting, Auditing and Accountability Journal 21 (7), 933-954.

Darnall, N., Seol, I., Sarkis, J., 2009. Perceived stakeholder influences and organizations' use of environmental audits. Accounting, Organisations and Society 34 (2), 170-187.

Dekker, H.C., 2008. Partner selection and governance design in interfirm relationships. Accounting, Organisations and Society 33 (7-8), 915-941.

Donaldson, T., Preston, L.E., 1995. The stakeholder theory of the corporation: Concepts, evidence and implications. The Academy of Management Review 20 (1), 65-91.

Dubois, A., and Gadde, L.-E. 2002. Systematic Combining: An Abductive Approach to Case Study. Journal of Business Research 55, 553-560.

Ferguson, J., Collison, D., Power, D., Stevenson, L., 2005. What are recommended accounting textbooks teaching students about corporate stakeholders? The British Accounting Review 37 (1), 23-46.

Ferreira, A., Otley D., 2009. The design and use of performance management systems: An extended framework for analysis. Management Accounting Research 20 (4), 263-282.

FNBE (Finnish national board of education), 2010. Opetus- ja kulttuuritoimen rahoitusYksikköhintojen ja rahoituksen määräytyminen vuonna 2010. ISBN: 978-952-134537-1, Oppaat ja käsikirjat 2010:9. 
Freeman, R.E., 1984. Strategic Management: A Stakeholder Approach. Pitman, Boston, MA.

Freeman, R. E., Wicks, A.C., Parman, B., 2004. Stakeholder theory and 'the corporate objective revisited'. Organizational Science 15 (3), 364-369.

Frooman, J., (1999) Stakeholder Influence Strategies. The Academy of Management Review. 24 (2), 191-205.

Hillman, A.J., Withers, M.C., Collins, B.J., 2009. Resource Dependence Theory: A Review. Journal of Management 35 (6), 1404-1427.

Jensen, M.C., 2001. Value maximization, stakeholder theory, and the corporate objective function. European Financial Management 7 (3), 297-317.

Kamminga, P.E., van der Meer-Kooistra, J., 2007. Management control patterns in joint venture relationships: a model and an exploratory study. Accounting, Organisations and Society 32 (1-2), 131-154.

Kaplan, R.S., Norton, D.P., 1996. Balanced Scorecard. Translating Strategy into Action. Harvard Business School Press, Boston.

Kraus, K., Lind, J., 2010. The impact of the corporate balanced scorecard on corporate control-A research note. Management Accounting Research 21 (4), 265-277.

Li, P., Tang, G., 2009. Performance measurement design within its organisational contextEvidence from China. Management Accounting Research 20 (3), 193-207.

Lukka, K., Modell, S., 2010. Validation in interpretive management accounting research. Accounting, Organisations and Society 35 (4), 462-477.

McKinnon, J., 1988. Reliability and Validity in Field Research: Some Strategies and Tactics. Accounting, Auditing and Accountability Journal 1 (1), 34-54.

MEC (Ministry of Education), 2010. Polytechnic education in Finland. http://www.minedu.fi/OPM/Koulutus/ammattikorkeakoulutus/?lang=en (downloaded 8. December 2010)

Meyer, J.W. and Rowan, B., 1977. Institutionalized organizations: Formal structure as myth and ceremony. American Journal of Sociology 83 (2), 340-63.

Micheli, P., Manzoni, J.-F., 2010. Strategic Performance Measurement: Benefits, Limitations and Paradoxes. Long Range Planning 43 (4), 465-476.

Modell, S., 2009. Institutional research on performance measurement and management in the public sector accounting literature: a review and assessment. Financial Accountability \& Management 25 (3), 277-303.

Mouritsen, J., 2005. Beyond accounting change: design and mobilization of management control systems. Journal of accounting \& organizational change (1), 97-113.

Mäkelä, H., Näsi, S., 2010. Social responsibilities of MNCs in downsizing operations: A Finnish forest sector case analysed from the stakeholder, social contract and legitimacy theory point of view. Accounting, Auditing and Accountability Journal 23 (2), 149-174.

Orij, R., 2010. Corporate social disclosures in the context of national cultures and stakeholder theory. Accounting, Auditing and Accountability Journal 23 (7), 868-889.

Pfeffer, J., Salancik, G., 2003. The External Control of Organizations: A Resource Dependence Perspective. Stanford University Press. 
Pääkkönen, J., 2010. Koulutuksen markkinoilla - arvioita ammattikorkeakoulujen tehokkuuseroista ja niiden syistä (In the markets of education - an evaluation of the differences in the efficiency ratios between UAS and their reasons). VATT Valmisteluraportit 6. ISBN 978-951-561-949.

Rhenman, E., 1964. Företagsdemokrati och företagsorganisation (Stockholm: Thule).

Rhenman, E., 1968. Industrial Democracy and Industrial Management, Tavistock, London.

Ryan, B., Scapens, R.W., Theobald, M., 2002. Research Method and Methodology in Finance and Accounting. South-Western, Cengage Learning, UK.

Salminen, H., Ylä-Anttila, P., 2010. Ammattikorkeakoulujen taloudellisen ja hallinnollisen aseman uudistaminen (The restructuration of finance and organizational position in the Universities of applied sciences; our translation). Opetus- ja kulttuuriministeriön julkaisuja 2010:23. ISBN 978-952-485-967-7.

Simons, R., 1995. Levers of Control: How Managers Use Innovative Control Systems to Drive Strategic Renewal. Harvard Business School Press, Boston, MA.

Siti-Nabiha, A. K., and Scapens, R. W., 2005. Stability and change: An institutionalist study of management accounting change. Accounting, Auditing \& Accountability Journal $18(1), 44-73$.

Sundin, H., Granlund, M., Brown, D.A., 2010. Balancing Multiple Competing Objectives with a Balanced Scorecard. European Accounting Review 19 (2), 203-246.

Vaivio, J., 2008. Qualitative management accounting research: rationale, pitfalls and potential. Qualitative Research in Accounting and Management 5 (1), 64-86.

Waddock S.A., Bodwell C., Graves S.B., 2002. Responsibility: The new business imperative. Academy of Management Executive 16 (2), 132-148. 